POLLACK PERIODICA

An International Journal for Engineering and Information Sciences

DOI: $10.1556 / 606.2017 .12 .2 .3$

Vol. 12, No. 2, pp. 29-41 (2017)

www.akademiai.com

\title{
PV SYSTEM AUTO-SIZING WITH BATTERY ENERGY STORAGE BASED ON GPS COORDINATES
}

\author{
${ }^{1}$ Balint David OLASZI, ${ }^{2}$ Jozsef LADANYI \\ Department of Electric Power Engineering, Power System and Environment Group \\ Faculty of Electric Engineering, Budapest University of Technology and Economics \\ H-1521 Budapest, Hungary, e-mail: 1 olaszi.balint@vet.bme.hu, ${ }^{2}$ ladanyi.jozsef@vet.bme.hu
}

Received 11 December 2016; accepted 24 May 2017

\begin{abstract}
The paper presents a photovoltaic system auto sizing algorithm with irradiance and shading calculation, which uses the photovoltaic geographical information system database. This calculation step is a very labor intensive task, which require a lot of iterative design time to find the optimum alternative. Based on measurement data, monthly irradiance correction matrixes are simulated to completely describe the yearly irradiance loss caused by shading of the nearby objects. As result, a function between the shaded area and the yearly energy loss can be obtained. Furthermore, photovoltaic modules can be auto-allocated on a given area according to the boundary conditions. Taking into consideration the photovoltaic installers' pricing system, a complete photovoltaic auto-sizing algorithm can be presented, which greatly reduces the time spent on quotation writing. This paper also includes a battery energy storage sizing algorithm according to the given economic conditions, which extends the capability of the photovoltaic system auto-sizing algorithm.
\end{abstract}

Keywords: Renewable energy, Photovoltaic systems, Convex optimization, Shading calculation, Economic optimization

\section{Introduction}

The field of PhotoVoltaic (PV) system sizing is a relatively well published area due to the widespread application of the PV systems [1]. However, there is still room for improvement in the field of economy-auto-sizing of PV-systems combined with Battery Energy Storage Systems (BESS). To be more specific, even the state-of-art PV system sizing software, like Photovoltaic Geographical Information System (PVSOL) offers PV module auto allocation without including the nearby objects shading zone. The 
simplified shading zone calculation is based on the yearly energy loss and the total irradiance calculation of the defined PV system.

The main differences between the presented algorithm and the mentioned software is that the algorithm only utilizes the satellite image on which the boundary conditions are defined and it is extended with a PV installer pricing system in comparison with the other methods, which do not include pricing. Moreover, other methods require that a 3D model of the PV installation layout must be built by the user. As a result, it takes significantly more time to create and PV system quote compared to the presented algorithm.

This paper presents an early energy loss shading calculation model, which is paired with convex optimization respective of the maximal number of the PV modules, which can be located on any given rooftop. Furthermore, the obtained result can be used for optimal BESS sizing in respective of the state-of-art energy storage technologies and installation costs. With the combination of the mentioned techniques, a new truly unique PV system auto-sizing algorithm can be presented.

The controlled operation of an AC-connected BESS can be seen in Fig. 1, which consists of two AC/DC inverters, PV modules, battery storage and all together two electric meters. As a result, the two electric meters make it possible that the PV system production and the consumed electric energy from the grid can be measured separately. The energy storage system measures the load-balance separately and it is controlled by its own logic.

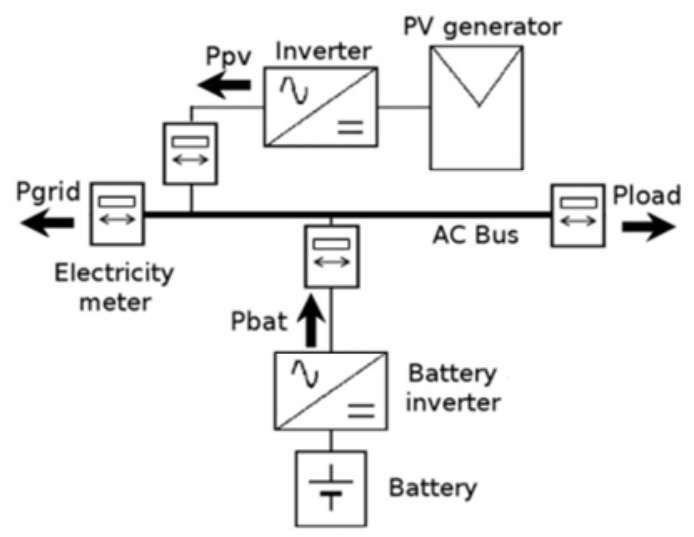

Fig. 1. PV system with a separately metered AC coupled battery energy storage

\section{Irradiance calculation}

The irradiance calculation is based on the PVGIS 'climate' irradiance database [2], [3] in monthly resolution. However the dependency of the monthly irradiance in the function of the orientation and slope has to be simulated to create a working irradiance calculation (Fig. 2 and Fig. 3). 


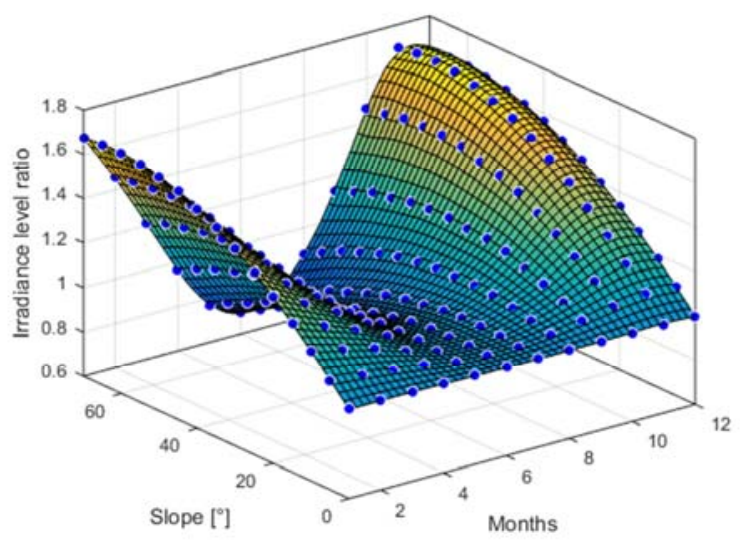

Fig. 2. Monthly irradiance level in the function of the slope in case of south orientation

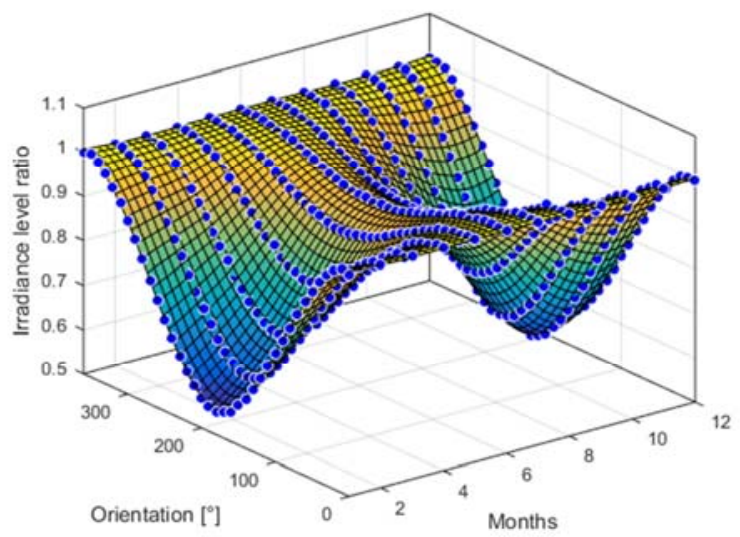

Fig. 3. Monthly irradiance level in the function of the orientation in case of $15^{\circ}$ slope

The slope and orientation dependency based on daily irradiance calculation in 15 minutes resolution.

The location of the sun on the azimuth is in linear connection with the time, therefore, when a sun reaches a certain time given by the azimuth, then the light can reach the surface and it is not blocked by a shading object. Basically, the daily irradiance is cut at the given azimuth by the shading object [2], [3], Plataforma Solar de Almerýa (PSA) (1), Airmass (2), Airmass Intensity (3) and surface irradiance (4) were utilized, all of these equations are necessary to calculate the yearly irradiance, which reaches the PV modules, from the yearly horizontal irradiance;

$$
\cos \left(\theta_{S}\right)=\sin \left(\alpha_{s}\right)=\sin (\vartheta) \sin (\delta)+\cos (\vartheta) \cos (\delta) \cos (h)
$$




$$
\begin{aligned}
& A M=\frac{1}{\cos \left(\theta_{s}\right)}, \\
& I_{D}=I_{0} \cdot 0.7 \cdot A M^{0.678}, \quad \text { at sea level, } \\
& I_{\text {Module }}=I_{D} \cdot \frac{\sin (\gamma+\beta)}{\sin (\gamma)},
\end{aligned}
$$

where the list of nomenclatures is summarized in Table I.

\begin{tabular}{|c|c|c|c|}
\hline Symbol & Description & Symbol & Description \\
\hline$\theta_{S}$ & Solar zenith angle & $\alpha$ & azimuth \\
\hline$\alpha_{s}$ & Solar elevation angle & $s$ & shading angle \\
\hline$h$ & Hour angle in local solar time & $s_{l}$ & shading angle limit \\
\hline$\delta$ & Current declination of the Sun & $m$ & months \\
\hline$\vartheta$ & Local latitude & $S M_{y}$ & $\begin{array}{l}\text { Yearly shading matrix (East and } \\
\text { West) }\end{array}$ \\
\hline$I_{0}$ & Solar constant $1353 \mathrm{~W} / \mathrm{m}^{\wedge} 2$ & $S M_{m}$ & $\begin{array}{l}\text { Monthly shading matrix (East and } \\
\text { West) }\end{array}$ \\
\hline$I_{D}$ & $\begin{array}{l}\text { Direct horizontal irradiance at } \\
\text { sea level }\end{array}$ & $E_{m}$ & Monthly energy matrix \\
\hline$\gamma$ & Elevation angle & $S L_{m}$ & $\begin{array}{l}\text { Yearly shading loss limit (East } \\
\text { and West) }\end{array}$ \\
\hline$\beta$ & Tilt angle (PV module) & $x_{i}$ & Width of the PV modules \\
\hline
\end{tabular}

Table I

Nomenclatures

The irradiance calculation contains three major simplifications, the first is that the estimated loss due to the temperature is set to $9 \%$ and the estimated loss due to angular reflectance effects is $2.8 \%$. Furthermore, other losses like cable, inverter and dusting are set to $8 \%$ as in [4], [5]. It is important to mention that the monthly irradiance ratio in the function of the yearly irradiance depends on the latitude and the local wheatear conditions; therefore, it can be only obtained by measurement. In Fig. 2 and Fig. 3 the slope and orientation can be seen in the function of the irradiance in monthly resolution. The simulation was run on the following GPS coordinates; $47.677913^{\circ}$ latitude, $16.591236^{\circ}$ longitudes, as an example.

In the irradiance calculation an irradiance slope function is defined for every integer orientation angle and in case of the orientation, it is defined for every integer slope angle. These matrixes are the corner stone of the irradiance and shading calculation algorithm.

In Fig. 2 it can be seen that the monthly irradiance greatly increases in the winter month due to the fact the in winter the sun orbiting in much lower elevation angle compared with the summer months. Fig. 3 shows the dependency between the irradiance and orientation of the solar arrays. According to the simulation results, the 
increase in the slope greatly reduces the irradiance in the winter months in comparison with the flat array.

\section{Auto-sizing the PV array}

The size of a PV system is related to the installation area. This area is usually determined by survey or by satellite image measurement and the processing is done by computer aided design software which is a time consuming method. The irradiance is calculated by using PVGIS an open source irradiance database. With the developed method this process can take up ten times less time interval, then with the traditional methods like using AutoCAD, Excel and the PVGIS.

The first step in the PV system sizing is to determine the maximum size of the PV system, which is done by finding the geometry constrains of the installation area. The second step is to calculate the energy yield of the system. It is known that the yearly energy need, the exact size of the PV system can be predicted. The last step is to calculate the installation price and the payback time of the PV system using real PV installer data and yearly irradiance simulation corrected by shading.

\subsection{Determine the maximum number of the PV modules}

The PV module allocation is a time consuming process and it could be automated with the help of convex optimization, by giving the predetermined boundary conditions. The following equation (5) describes the problem:

$$
\sum_{C} \alpha_{C}, \quad i x_{C} \geq \beta_{i}, \quad i=1, \cdots, n, \quad x_{C} \geq 0,
$$

where $\beta_{i}$ is the sum of heights of the PV modules and $x i$ is the width of the PV modules. The $\alpha_{C}$ parameter is the number of occurrences of $x_{i}$ in the configuration $C$ (Fig. 4). Furthermore, $C$ is the resultant condition, which is determined by the edge points of a polygon given by the user (GPS coordinates) and by shading zone edge points, which are calculated by the nearby shading objects (like a tree). The restricted zone is caused by the shading of the PV module mounting system (Fig. 4) and by the territory objects as well. The shading is defined by boundary GPS coordinates, height and by the desired yearly PV string loss of the object.

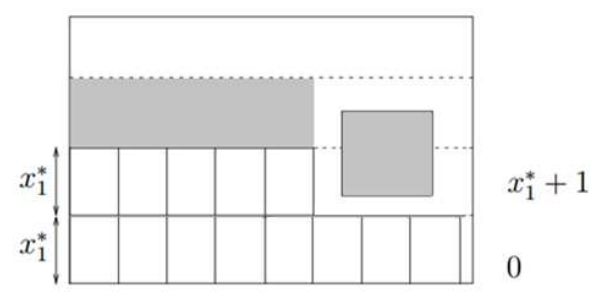

Fig. 4. PV modules and the initial boundary conditions (grey) visualized 
Because of the orientation of the GPS image can be calculated and knowing that the lower latitude GPS coordinates will determine the orientation of PV module lines. Additionally, the PV mounting system is installed on a $35^{\circ}$ slope roof; therefore, the top view the PV module size can be easily calculated. As result, the auto-sizing algorithm only uses the edge GPS coordinates of the installation area and the GPS coordinates of the territory objects the define the boundary conditions and to start to convex optimization.

In Fig. 5 the boundary conditions of a residential size $4.42 \mathrm{kWp}$ PV system can be seen, which are given by the user with the help of the satellite image (Sopron, Hungary). In Fig. 6 the exact position of the PV modules are calculated by convex optimization and located on satellite image.

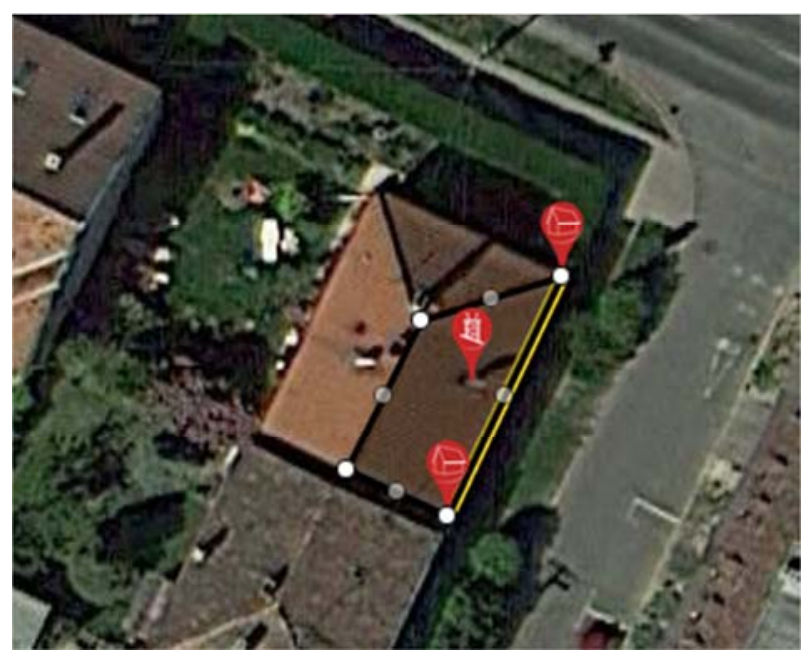

Fig. 5. Initial boundary conditions of the auto-sizing based on Google Maps API

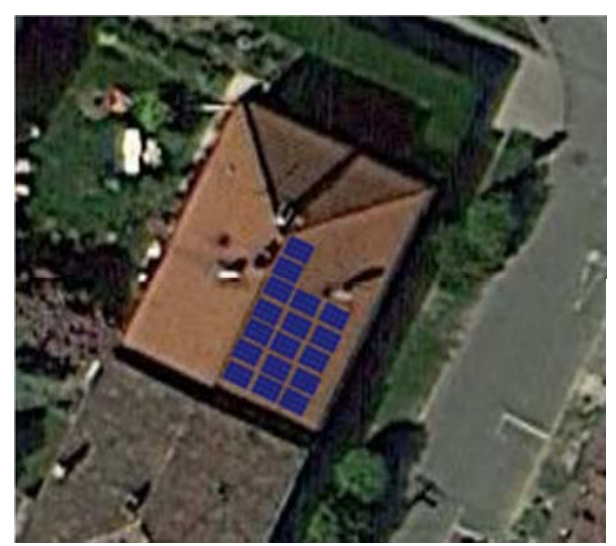

Fig. 6. PV modules allocation 
In Fig. 6 the result of auto-sizing can be seen, in the calculation there is no gap between the PV modules; it is only there for better visibility. The PV modules are sized according to the slope of the roof.

\section{Shading area calculation}

The shading zone is calculated by the height of the object, the implementation, orientation angle of the roof and finally by the time. However, in case of the yearly shading zone calculation, there are more variables to take into consideration. The yearly shading loss zone where the loss is higher than a certain limit can be calculated by the calculated orientation of the roof, the height and the location of the object. To determine the yearly shading loss level, the monthly levels has to be summed. To accomplish that, the previous monthly irradiance calculation has to be modified with a shading orientation matrix, which is corrected by the monthly irradiance in the function of the orientation and the slope (Fig. 2 and Fig. 3). Using this method, a given object shading zone can be calculated, furthermore, the shaded side of PV string is has to be taken into consideration - meaning by that - a PV string can be shaded East, West or both directions. Additionally, the shading loss is not started at the edge of the PV module but with a $5 \mathrm{~cm}$ offset because of the structure of the PV panels [5], [6].

The function works by the following way:

$$
\begin{aligned}
& \text { for } a \text { from } 0^{\circ} \text { to } 180^{\circ}, \text { for } s \text { from } 0^{\circ} \text { to } 90^{\circ}, \text { month from } 1 \text { to } 11 \text {, } \\
& S M_{y}(a, s)=E_{m}(m) \cdot S M_{m}(a, s, m), \\
& \text { if } S M_{y}(a, s)<S L_{l} \text { then } s_{l}(a)=s .
\end{aligned}
$$

Knowing the tilt of the roof, the exact distance shading contour can be obtained using the law of sinus. The shading matrixes were simulated using the monthly irradiance data and GPS coordinates of the chosen location and it is corrected by the given azimuth.

Fig. 7 shows the simulated shading, according to the given yearly shading loss. The shading caused by $1.5 \mathrm{~m}$ height $0.6 \mathrm{~m}$ wide and long chimney and the simulation was run in Sopron, Hungary. The shading calculation contains two major simplifications; the first is that every shading object is taken into consideration as it can shade the PV modules by east and west as well. The second simplification is that the simulation was only run in GPS coordinate.

\section{Storage and PV system technologies}

The presentation of the most common PV and storage technologies are important to understand reason behind the product choices of the case study. 


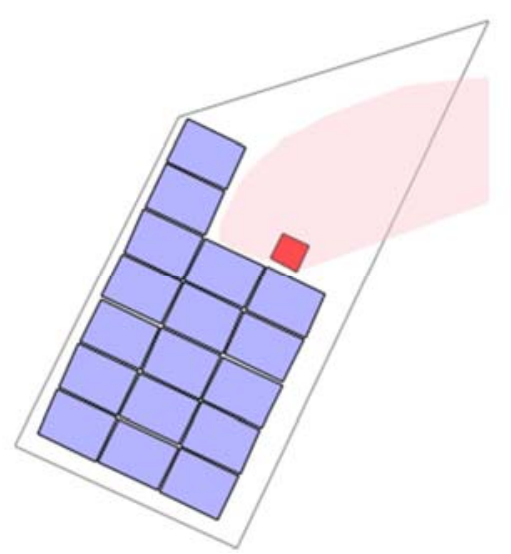

Fig. 7. Shading zone simulation with 5\% yearly energy shading energy loss in case of a Sopron, Hungary located real estate

\section{Pb-acid}

More than 100 years old but refined deep-cycle $\mathrm{Pb}$-acid technology is starting to loss its competitiveness in the storage business due to their relative low discharge cycles, which is in the range of 2000-2500 at the maximum of 50\% Dept of Discharge (DoD), and due to their poor cycle efficiency which is around $67 \%$ including the AC/DC conversion in case of a AC coupled system [7], [8].The deep-cycle Pb-acid technology has low energy density $30-45 \mathrm{Wh} / \mathrm{kg}$, although low specific price as well $400-600$ Euro/usable kWh.

\section{$\mathrm{LiFeO}_{4}$}

In case of lithium-ion-iron-phosphate technology the discharge cycle number is significantly higher which is around 6000 or even more at the maximum of $80 \%$ of DoD and its cycle efficiency is $85 \%$ in case of AC coupled version. The drawback of the $\mathrm{LiFeO} 4$ technology is the moderate energy density $80-120 \mathrm{Wh} / \mathrm{kg}$ and higher specific price 900-1100 Euro/usable kWh compared to the lithium-ion technology [7], [8].

\section{Lithium-ion}

Lithium-ion batteries have become the most important storage technology in the areas of portable and mobile applications and gained ground in storage applications as well. This technology possess significantly high energy density in the range of $150-200 \mathrm{Wh} / \mathrm{kg}$ and moderate specific price $800-1100$ Euro/usable $\mathrm{kWh}$ made it suitable for daily energy storage applications. Nevertheless, the lithium-ion batteries can be discharged more than 5000 times in case of $80 \%$ DoD [7], [8], [9] which property is essential in storage applications. 


\section{PV-System}

In case of a PV system, the price of the PV modules and the inverter are the most dominating, therefore, it is crucial to lower the price of the equipment. However, according to the Original Equipment Manufacturer (OEM) specifications, there is minimal difference between the PV module properties besides the peak power rating. As a matter of fact, the cheaper PV modules are always better in economical respective. Unfortunately, usually the cheaper modules have lower power ratings then their specification. The cheaper inverters have higher fault rate and a hardly enforceable warranty. As result, a good performance/price ratio PV module and inverter was chosen for the simulation. Nowadays, the polycrystalline offer the best price/performance ratio in comparison with the mono-crystalline or thin-film PV modules, therefore, this type was chosen for the case study [7], [8], [10].

\section{Case study on an economic optimization of storage and PV system for a grid connected residential household}

\section{Demonstration of the implemented algorithm}

The PV module and BESS optimization algorithm is demonstrated in [11]. The algorithm can be applied for residential home owners who want to know more about their PV system potential and the estimated price and income of a PV system.

\section{Measurement data}

Yearly production data of a $2.5 \mathrm{kWp}$ system was registered in Sopron, Hungary in 15 minutes resolution. The result is similar to the conditions in Munich, Germany, which area is the cradle of the Battery Energy Storage System (BESS) systems. The economic conditions are based on German pricing and subsidy system, as of 2016 [11].

The initial PV system and BESS equipment parameters were cited in Table II for the chosen case study.

Case study

The economic optimization is run according to the following parameters (Table III):

- German subsidy conditions;

- Predefined load profile;

- $\quad$ Predefined size of PV system;

- Irradiance simulation results;

- Type of BESS and OM parameters;

- Depreciation of the BESS based on the discharge cycles;

- Charge and discharge efficiency of BESS;

- Installation prices. 
The optimal BESS size is always the result of the installation and product prices and the product properties [12], [13], [14], [15]. [16]. Therefore, the Pb-acid batteries are not best option due to their low discharge cycles, even considering their low prices. Altogether, a Sonnenbatterie Eco $6 \mathrm{LiFeO}_{4} \mathrm{BESS}$ was chosen in an AC connected configuration (Fig. 8) [17].

\section{Table II}

Initial conditions for PV system in the economic optimization software

\begin{tabular}{|c|c|c|c|}
\hline $\begin{array}{l}\text { Parameter } \\
\text { (STC condition) }\end{array}$ & Condition & Parameter & Condition \\
\hline $\begin{array}{l}\text { Chosen type of PV } \\
\text { module }\end{array}$ & $\begin{array}{l}\text { Sharp NDRC- } \\
260\end{array}$ & $\begin{array}{l}\text { Ambient temperature } \\
\text { and reflectance loss }\end{array}$ & $11.8 \%$ \\
\hline PV module peak power & $260 \mathrm{Wp}[18]$ & Module efficiency & $15.8 \%[18]$ \\
\hline $\begin{array}{l}\text { Performance warranty } \\
\text { after } 25 \text { years }\end{array}$ & $80 \%[18]$ & $\begin{array}{l}\text { Type of the chosen } \\
\text { inverter }\end{array}$ & $\begin{array}{l}\text { ABB TRIO- } \\
\text { 5.8-TL-OUTD } \\
{[19]}\end{array}$ \\
\hline $\begin{array}{l}\text { Temperature power } \\
\text { coefficient }\end{array}$ & $\begin{array}{l}0.41 \% / \mathrm{C}^{\circ}[18], \\
{[16]}\end{array}$ & $\begin{array}{l}\text { Peak DC power of the } \\
\text { inverter }\end{array}$ & $6050 \mathrm{~W}$ \\
\hline Open circuit voltage & $37.7 \mathrm{~V}$ [18] & $\begin{array}{l}\text { Peak AC power of the } \\
\text { inverter }\end{array}$ & $5800 \mathrm{~W}[19]$ \\
\hline Short circuit current & $9.01 \mathrm{~A}[18]$ & $\begin{array}{l}\text { Warranty ( } 25 \text { years } \\
\text { optional) }\end{array}$ & 5 years \\
\hline $\begin{array}{l}\text { Maximum Power } \\
\text { voltage }\end{array}$ & $30.5 \mathrm{~V}[18]$ & Operating voltage range & $300-800 \mathrm{~V} \mathrm{DC}$ \\
\hline $\begin{array}{l}\text { Maximum power } \\
\text { current }\end{array}$ & $8.51 \mathrm{~A}[18]$ & Peak efficiency & $98 \%[19]$ \\
\hline PV module number & 17 piece & EURO/CEC efficiency & $97.4 \%[19]$ \\
\hline $\begin{array}{l}\text { PV system (SOC) peak } \\
\text { power }\end{array}$ & $4.42 \mathrm{kWp}$ & $\begin{array}{l}\text { Installation price of PV } \\
\text { system }\end{array}$ & 8470 EUR \\
\hline $\begin{array}{l}\text { PV system yearly } \\
\text { energy production }\end{array}$ & $5049 \mathrm{kWh}$ & $\begin{array}{l}\text { Payback time ( } 12.31 \\
\text { EUR Cent fixed feed-in- } \\
\text { tariff) }\end{array}$ & 13.62 years \\
\hline
\end{tabular}

The simulation results in Fig. 8 were obtained by simulating the BESS behavior in 15 minutes resolution in the case study. In the simulation, easy to use bang-bang controller logic was utilized. As a result, when the PV system produces more energy than the actual consumption, then the surplus energy is going to be stored in $\mathrm{AC}$ coupled BESS and released through its own DC/AC inverter when the load is higher than the PV production. The inverter, battery charging/discharging and aging losses were taken into consideration. Altogether in the first case $31 \%$ of yearly energy usage or $1241 \mathrm{kWh}$ has been stored by the BESS and $40 \%$ of the overall energy consumption was covered by the grid. In the second case, where the yearly energy usage was reduced to $2500 \mathrm{kWh}$, which is twice as less as the PV energy production, a bit more $35.8 \%$ (894 kWh) was covered by the BESS. The PV self-consumption was $31.6 \%$ (790 kWh) and from the grid $32.6 \%(815 \mathrm{kWh})$ of the total energy consumption was covered. Remarkably, the PV system fed in $3208 \mathrm{kWh}$ into the electric grid which is more than $60 \%$ of the total energy produced by the PV system 
Table III

Initial conditions for BESS in the economic optimization software

\begin{tabular}{|c|c|c|c|}
\hline Parameter & Condition & Parameter & Condition \\
\hline Chosen type of BESS & $\begin{array}{l}\text { AC connected } \\
\text { Lithium iron } \\
\text { phosphate } \\
\text { (Sonnenbatterie } \\
\text { Eco 6) }\end{array}$ & $\begin{array}{l}\text { Price of the battery } \\
\text { inverter (Sonnenbatterie) }\end{array}$ & $3500 €[8]$ \\
\hline Usable capacity & $6 \mathrm{kWh}[9]$ & $\begin{array}{l}\text { PV energy Production } \\
\text { ( } 4.5 \mathrm{kWp} \text { South oriented } \\
\text { PV system) }\end{array}$ & $5069 \mathrm{kWh}$ \\
\hline $\begin{array}{l}\text { Maximum cycle } \\
\text { efficiency of the AC } \\
\text { coupled } \\
\text { Sonnenbatterie ECO } \\
\text { Lithium Iron } \\
\text { Phosphate BESS }\end{array}$ & $85 \%[8]$ & Yearly energy demand & $\begin{array}{l}29,1 € \text { Cent } \\
{[20]}\end{array}$ \\
\hline $\begin{array}{l}\text { DoD of the } \\
\text { Sonnenbatterie ECO } \\
\text { BESS }\end{array}$ & $100 \%[11]$ & Feed-in tariff (Germany) & $2 \%[20]$ \\
\hline $\begin{array}{l}\text { Lifetime of the } \\
\text { Lithium Iron } \\
\text { Phosphate } \\
\text { Sonnenbatterie ECO } \\
\text { BESS (100\% DoD, } \\
\left.25 C^{\circ},\right)\end{array}$ & 6000 Cycles [9] & $\begin{array}{l}\text { Residential Energy price } \\
\text { (Germany) }\end{array}$ & $4000 \mathrm{kWh}$ \\
\hline $\begin{array}{l}\text { Rated power of the } \\
\text { Sonnenbatterie ECO's } \\
\text { battery inverter }\end{array}$ & 2.5-3.3 kW[9] & $\begin{array}{l}\text { Yearly average energy } \\
\text { price increase }\end{array}$ & $2 \%$ \\
\hline Installation cost & $500 €[8]$ & Yearly energy demand & $4000 \mathrm{kWh}$ \\
\hline
\end{tabular}

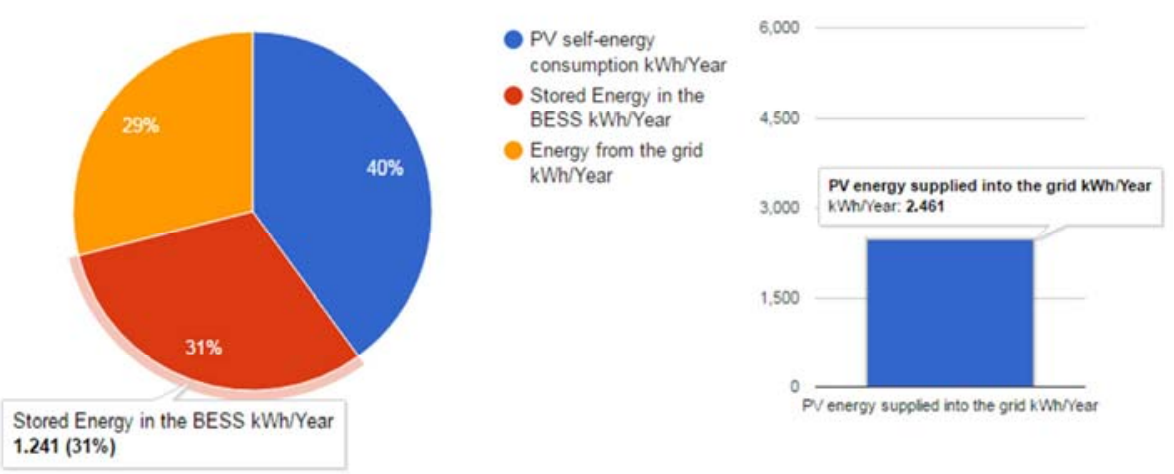

Fig. 8. Energy Mix and the PV overproduction of the BESS system 


\section{Conclusion}

This paper presented a new, fully-integrated method to size PV system rapidly. Although elements of this method can be found in the literature, however, the integration all of the parts together it is truly unique achievement. Furthermore, a new approach is introduced in the PV module allocation method, in which case yearly shading loss of the nearby string as a new initial boundary condition was taken into consideration. The obtained results are validated by real world PV systems, meaning that the algorithm can allocate exactly the same number of PV modules on a given rooftop as it can be mounted effectively in the reality.

The irradiance and shading calculation is validated by PVGIS database; however, the yearly irradiance in the function of slope, orientation and shading angle has to be calculated in addition. The introduction of an 'easy-to-use' BESS-size economic optimization application can offer significant help to the average user to find the bestsuited BESS product for his/her needs. The presented software also has the advantage that it only utilizes easily accessible data in comparison with other solutions presented in the literature where the residential peak power demand must be defined a priori in order to determine the optimal BESS size. Furthermore, the BESS size algorithm contains predefined products and the constantly changing number of discharge cycles in the function of the technology, was taken into consideration in the economic optimization application presented.

\section{References}

[1] Raza M. Q., Nadarajah M., Ekanayake C. On recent advances in PV output power forecast, Solar Energy, Vol. 136, 2016, pp. 125-144.

[2] Ineichen P., Barroso C. S., Geiger B., Hollmann R., Marsouin A., Müller R. Satellite application facilities irradiance products: hourly time step comparison and validation over Europe, International Journal of Remote Sensing, Vol. 30, No. 21, 2009, pp. 5549-5571.

[3] Huld T., Müller R., Gambardella A. A new solar radiation database for estimating PV performance in Europe and Africa, Solar Energy, Vol. 86, No. 6, 2012, pp. 1803-1815.

[4] Lu H., Lu L., Wang Y. Numerical investigation of dust pollution on a solar photovoltaic (PV) system mounted on an isolated building, Applied Energy, Vol. 180, 2016, pp. 27-36.

[5] de Simón-Martín M., Díez-Mediavilla M., Alonso-Tristán C. Shadow-band radiometer measurement of diffuse solar irradiance, Calculation of geometrical and total correction factors, Solar Energy, Vol. 139, 2016, pp. 85-99.

[6] Zaihidee F. M., Mekhilef S., Seyedmahmoudian M., Horan B. Dust as an unalterable deteriorative factor affecting PV panel's efficiency: Why and how, Renewable and Sustainable Energy Reviews, Vol. 65, 2016, pp. 1267-1278.

[7] Hollinger R., Wille-Haussmann B., Erge T., Sönnichsen J., Stillahn T., Kreifels K., Wittwer K. Kurzgutachten zur Abschätzung und Einordnung energiewirtschaftlicher, ökonomischer und anderer Effekte bei Förderung von objektgebunden elektrochemischen Speichern, SPEICHERSTUDIE 2013, Fraunhofer-Institut für Solare Energiesysteme, ISE, 2013.

[8] Lorenz C., Schröder G. Wirtschaftlichkeit Batteriespeicher, Leipziger Institut für Energie GmbH, Leipzig, Germany, 2014.

[9] Sonnenbatterie Eco Battery Storage OEM Specification, (http://www.seacoastenergy.com/ new_items/Resources/sonnen_eco_US\%20Datasheet_March\%202016.pdf, (last visited 2 June 2016). 
[10] Won M. S., Ju K. S., Hur D. Optimized installation and operations of battery energy storage system and electric double layer capacitor modules for renewable energy based intermittent generation, Journal of Electrical Engineering Technology, Vol. 8, No. 2, 2013, pp. 238-243.

[11] European Energy Exchange Market Data, 2015, http://www.eex.com/en/ (last visited 2 September 2016).

[12] Beaudin M., Zareipour H. Home energy management systems: A review of modeling and complexity, Renewable and Sustainable Energy Reviews, Vol. 45, 2015, pp. 318-335.

[13] Sharma V., Chandel S. S. Performance and degradation analysis for long term reliability of solar photovoltaic systems, A review, Renewable and Sustainable Energy Reviews, Vol. 27, 2013, pp.753-767.

[14] Zakeri B., Syri S. Electrical energy storage systems: A comparative life cycle cost analysis, Renewable and Sustainable Energy Reviews, Vol. 43, 2015, pp. 569-596.

[15] http://www.bundesnetzagentur.de/cln_1411/DE/Sachgebiete/ElektrizitaetundGas/Unterneh men_Institutionen/ErneuerbareEnergien/ZahlenDatenInformationen, (last visited 9 September 2015).

[16] Kota L., Jarmai K. Efficient algorithms for optimization of objects and systems, Pollack Periodica, Vol. 9, No. 1, 2014, pp. 121-132.

[17] Wirth H. Aktuelle Fakten zur Photovoltaik in Deutschland, Fraunhofer ISE, 2016.

[18] Sharp NC-RC260 PV module OEM Specification, http://www.sharp-cee.com/ cps/rde/ $\mathrm{xchg} / \mathrm{scee} / \mathrm{hs} . \mathrm{xsl} /$-/html/product-details-solar-modules-2189.htm?product=NDRC260, (last visited 2 September 2016).

[19] ABB Trio Inverter OEM Specification, https://www.google.hu/search?q=abb+trio\&oq $=\mathrm{abb}+$ trio\&aqs $=$ chrome..69i57j69i6015.2836j0j7\&sourceid=chrome\&ie=UTF-8, ， last visited 22 October 2016).

[20] Orosz T., Sleisz Á., Tamus Z. Á. Metaheuristic optimization preliminary design process of core-form autotransformers, IEEE Trans. Magn. Vol. 52, No. 4, 2016, pp. 1-10. 